\title{
TENACITY AND PERSISTENCE OF COPPER FUNGICIDES IN CITRUS SEEDLINGS UNDER SIMULATED RAINFALL ${ }^{1}$
}

\author{
ANTONIO EDUARDO FONSECA ${ }^{2 *}$, BRUNO DE MORAES NUNES ${ }^{3}$, JOÃO BATISTA FERREIRA JÚNIOR ${ }^{2}$
}

\begin{abstract}
The amount of fungicide that adheres to the leaf during spraying and the amount that remain on the leaf after weathering are the main factors that defines the amount of active residue on the leaf surface to effectively control plant pathogens. Thus, the objective of this work was to evaluate the tenacity and persistence of copper in citrus seedling leaves under simulated rainfall in Jaboticabal, State of São Paulo, Brazil. The evaluated variables were copper content, solution retention, surface tension and drop spectrum. A significant and inversely proportional linear relationship to drops $<100 \mu \mathrm{m}$ was found. The percentage of copper retained in leaves of citrus seedlings with copper fungicides of suspension concentrate (SC) formulations after simulated rainfall was greater than $80 \%$. Copper fungicides of SC formulations presented the lowest surface tension, allowing greater tenacity and persistence of copper on seedlings of citrus leaves after simulated rainfall and increased contact between the drops and leaf surface.
\end{abstract}

Keywords: Chemical control. Copper retention. Surface tension.

\section{TENACIDADE E PERSISTÊNCIA DE FUNGICIDAS CÚPRICOS EM MUDAS CÍTRICAS SOB CHUVA SIMULADA}

RESUMO - A quantidade de produto que adere a folha durante a pulverização e a quantidade de material que permanece na folha após a ação de intempéries são os principais fatores que determinam a quantidade do resíduo ativo na superfície das folhas para um efetivo controle de fitopatógenos. O objetivo deste trabalho, conduzido em Jaboticabal - SP, foi avaliar a tenacidade e persistência de cobre em folhas de mudas cítricas sob ação de chuva simulada. Foram analisadas as variáveis: teor de cobre, retenção de calda, tensão superficial e espectro de gotas. Observou-se relação linear inversamente proporcional e significativa ao volume de gotas $<100 \mu \mathrm{m}$. A porcentagem de teor de cobre retido em folhas de mudas cítricas após a simulação de chuva foi superior a $80 \%$ para os fungicidas cúpricos de formulações SC (suspensão concentrada). Os fungicidas cúpricos de formulações SC apresentaram as menores tensões superficiais, possibilitando maior tenacidade e persistência do cobre nas folhas de mudas cítricas após chuva simulada e permitindo o aumento do contato entre a gota e a superfície foliar.

Palavras-chaves: Controle químico. Retenção de cobre. Tensão superficial.

\footnotetext{
*Corresponding author

${ }^{1}$ Received for publication in. 04/23/2015; accepted in 03/28/2016.

${ }^{2}$ Department of Phytopathology, Universidade Estadual Paulista "Julio de Mesquita Filho", Jaboticabal, SP, Brazil; eduardofonseca.tva@gmail.com,joaojunioragr@hotmail.com.

${ }^{3}$ Department of Agricultural Science, Universidade do Estado de Minas Gerais, Ituiutaba, MG, Brazil; brunodemoraesnunes@gmail.com.
} 


\section{INTRODUCTION}

Spraying copper fungicides is one of the most traditional methods of disease control. Copper-based products have been used over 100 years, especially in rainy and fast vegetative growth periods. However, its formulations have evolved, from the Bordeaux mixture to concentrated suspension (SC) formulations, which are essential for the effectiveness of these products.

Adherence and persistence of pesticides on leaf surfaces of crops after the action of weather, are the main factors that define the amount of the active residue to effective control plant pathogens (RICH, 1954). The rainfall can be considered the most responsible for the accelerated degradation of fungicide deposits on plants. The interaction between rainfall and crop protection products is influenced by several factors, such as intensity, interval between application and rainfall, plant surface tissue characteristics, plant protection product used and its water solubility (CABRAS et al. 2001). Weber et al. (1937) stated that a single strong rainfall removes more fungicides from the leaf surface than several weak rainfalls, however, Hunsche et al. (2007) stated that the influence of rainfall on pesticide applications may vary, depending on the active ingredient and formulation.

The use of products of different formulations provides better performance of drops during application, minimizing mainly the drift and evaporation. Drops produced by spraying nozzles form a spectrum are qualified by parameters such as relative amplitude, numeric median diameter (NMD) and volumetric median diameter (VMD) (MOTA, 2011). VMD is the diameter of the drop that divides into two equal parts the volume of sprayed drops (ANTUNIASSI; BAIO, 2008).

The use of additives in the fungicide solution can improve the action of some fungicides, providing better adherence to the leaf surface and raise its persistence and tenacity, especially under rainfall (SHUERI; LATIN, 1991). There are four types of copper compounds which can be used for this purpose: copper oxychloride, copper hydroxide, copper sulfate and copper oxide. Their formulations may be wettable powder (WP), water-dispersible granules (WDG) and suspension concentrate (SC). The average size of the particles varies according to the active ingredient, ranging from 0.7 to $3.0 \mu \mathrm{m}$ and may be related to the control of phytopathogens (HARDY et al., 2007).

Thus, the objective of this study was to evaluate the tenacity and persistence of copper depending on different product formulations in leaves of citrus seedlings under simulated rainfall action.

\section{MATERIAL AND METHODS}

The experiment was conducted in a greenhouse of the Plant Protection Department of the Faculty of Agriculture and Veterinary Sciences (FCAV), São Paulo State University (Unesp), Jaboticabal SP. Citrus seedlings from the variety Pera Rio with about five to six pairs of true leaves were grown in three-liter plastic bags. Twenty-eight pesticide-free seedlings were selected, arranged in a row and applied to the point of dripping with seven copper fungicides (Table 1). $\mathrm{A} \quad \mathrm{CO}_{2}$-pressurized backpack sprayer with a 2-point bar with two spray nozzles (TXA8002VK ConeJet ${ }^{\circledR}$ ) spaced $0.5 \mathrm{~m}$ was used at constant pressure of 40 psi and moved at a constant speed, applying a total volume of approximately $80 \mathrm{~mL}$ planta $^{-1}$. After dried, five leaves from each treatment were collected for copper content retention analysis.

A simulated rainfall of $20 \mathrm{~mm}$ over a period of 10 minutes was performed 90 minutes after the application of treatments using an experimental prototype for applying controlled rain, which is calibrated according to the pressure and volume on its nozzles. After dried, five leaves from each treatment were again collected and the copper content retained was evaluated though an atomic absorption spectrum (AA Analist-100), in the laboratory of the Oxiquímica Agrociência company, Jaboticabal SP. The surface tension was evaluated using a tensiometer (Kruss ${ }^{\circledR}$ K10) on samples collected from the solutions used in the experiments, stored in labeled containers.

Drop spectrum analysis was conducted in the Particle Size Analysis Laboratory (LAPAR/FCAV/ UNESP-Jaboticabal), at a relative humidity above $45 \%$ and temperature below $30^{\circ} \mathrm{C}$, using a real-time particle analyzer (Mastersizer-S/Malvern Instruments $\left.{ }^{\circledR}\right)$. This device measures the particle size formed by the spray drops through the laser path deviation when passing through these particles, which is inversely proportional to the particle size, i.e., the smaller the particle, the greater the laser diffraction degree (ETHERIDGE et al., 1999). The device was calibrated to measure drops from 0.5 to $900 \mu \mathrm{m}$ (300 mm lens) and connected to a computer to store the data using the MastersizerS-2.19 software. Laser scans were performed every two milliseconds (500 readings per second) (CAMARA et al., 2008). There was an exhauster over the Mastersizer to remove particulate matter, preventing deposits on the lens or double laser readings, hindering the analysis accuracy (FERREIRA et al., 2007).

The variables analyzed were volumetric median diameter (VMD) (drop diameter that has $50 \%$ of the sprayed liquid volume consisting of drops smaller than this value), and spam (application uniformity percentage value of drops with diameters of 100,150 and $200 \mathrm{um}$ ). 
A pressurized spraying device was used to assess the drop spectrum, in order to get all the sprayed solution passing through the beam analyzer, and evaluate the average drop spectrum from each condition. The spray nozzle was located $25 \mathrm{~cm}$ above the optical beam (ASAE, 2000).

Table 1. Description of treatments.

\begin{tabular}{|c|c|c|c|}
\hline Active Ingredient & $\begin{array}{l}\text { Equivalent to } \\
\text { metal copper }\end{array}$ & Formulation & $\begin{array}{c}\text { Rate } \\
(\mathrm{L} \text { or } \mathrm{Kg} / 2000 \mathrm{~L})\end{array}$ \\
\hline Copper oxychloride & $350 \mathrm{~g} \mathrm{~L}^{-1}$ & $\mathrm{SC}$ & 2.5 \\
\hline Copper hydroxide & $350 \mathrm{~g} \mathrm{~L}^{-1}$ & $\mathrm{SC}$ & 2.5 \\
\hline Copper oxychloride & $500 \mathrm{~g} \mathrm{~kg}^{-1}$ & WP & 2.0 \\
\hline Copper hydroxide & $450 \mathrm{~g} \mathrm{~kg}^{-1}$ & WP & 2.0 \\
\hline Copper oxide & $750 \mathrm{~g} \mathrm{~kg}^{-1}$ & WP & 2.0 \\
\hline Copper oxychloride & $500 \mathrm{~g} \mathrm{~kg}^{-1}$ & WP & 3.6 \\
\hline Copper hydroxide & $538 \mathrm{~g} \mathrm{~kg}^{-1}$ & WDG & 2.5 \\
\hline
\end{tabular}

$\mathrm{SC}=$ suspension concentrate, $\mathrm{WP}=$ wettable powder, $\mathrm{WDG}=$ water dispersible granules.

The solution analysis for fungicide retention was carried out in the Department of Plant Protection (FCAV/Unesp-Jaboticabal) using the device shown in Figure 1, which had a spray nozzle TXA8002VK (ConeJet $\left.{ }^{\circledR}\right)$ positioned directly on the leaves and placed vertically on the support plate of a digital scale. The leaves were sprayed to the point of dripping and the retained solution was weighed. The retention results were expressed in $\mathrm{mg} \mathrm{cm}^{-2}$. The leaf area was assessed by an electronic integrator method (Liqueur 3000).

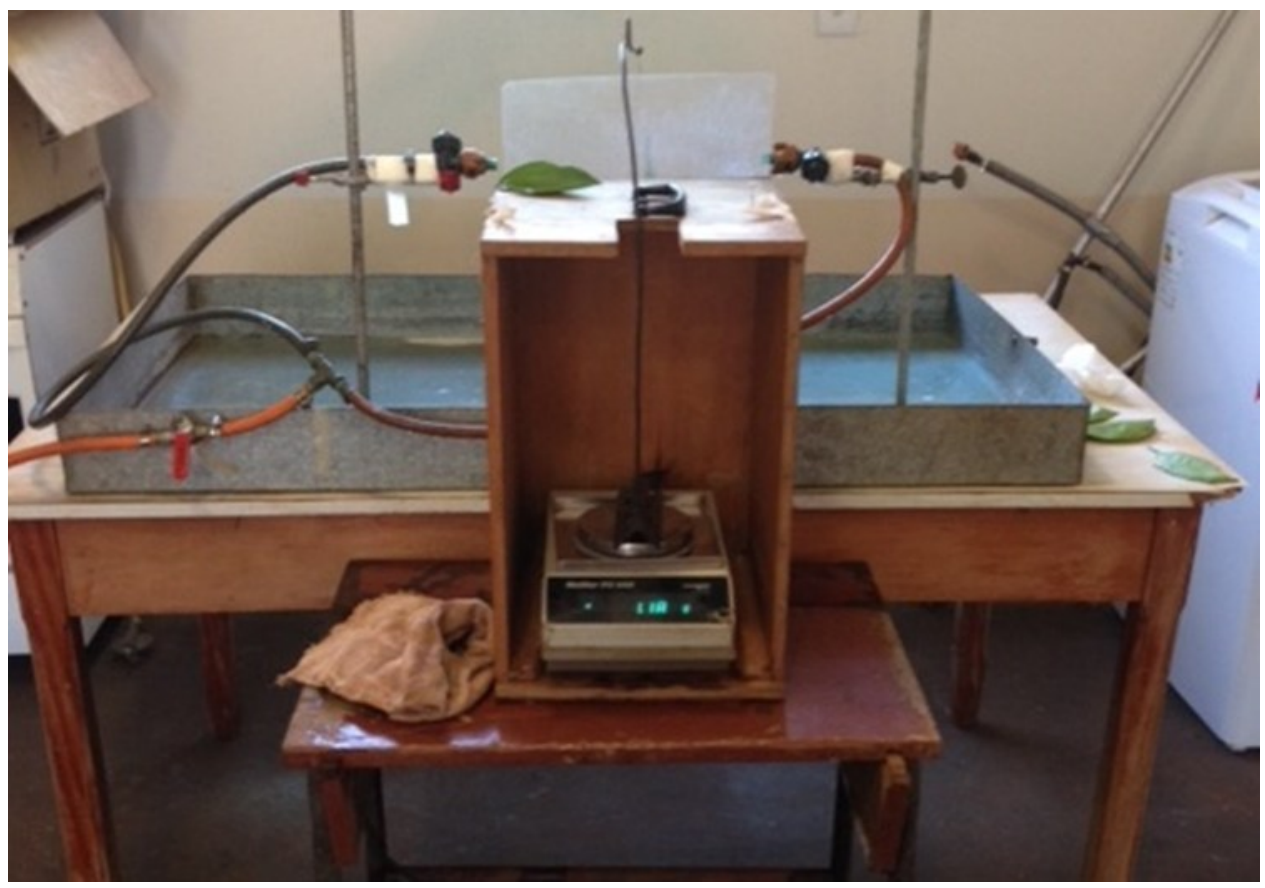

Figure 1. Device adapted to measure the retention of copper $\left(\mathrm{cm}^{2}\right)$ in leaves of citrus trees.

A completely randomized experimental design was used with four replications and seven treatments. Five citrus seedling leaves were considered per replication. The results were subjected to the $\mathrm{F}$ test and Scott Knott test at 1\% significance using the statistical software MSSA AGRI (CANTERI et al., 2001).

\section{RESULTS AND DISCUSSION}

The volumetric median diameter (VMD), relative amplitude (RA), percentage of drops smaller than $100,150,200 \mu \mathrm{m}$ and correlation between percentage of drops $<100 \mu \mathrm{m}$ and VMD are presented in Figures 2, 3, 4, 5 and 6.

The average values of VMD ranged from 122 to $128 \mu \mathrm{m}$. Despite the little variation, there was difference between treatments. The solution with copper oxide and copper oxychloride (WP; 3.6 $\mathrm{kg} / 2000 \mathrm{~L}$ ) had the greatest VMD and the treatment with copper hydroxide (SC), the lowest.

The relative amplitude ranged from 0.87 to 0.93 (Figure 3). Matthews (2000) stated that the relative amplitude expresses the variation of drop size, relating to the $\mathrm{VMD}$, and that the greater its 
value, the greater will be the variation of the drop size, and the smaller the value, the more homogeneous is the spectrum of drops. The VMD and COEF must be assessed together for characterize the spray. Separately, the VMD provides a reference value, without indicating the data dispersion around this value. The COEF indicates the homogeneity of the drop size. Thus, evaluating the effects of adjuvants in the drop size is important as well as to assess its effect on the drop uniformity (CUNHA et al., 2010).

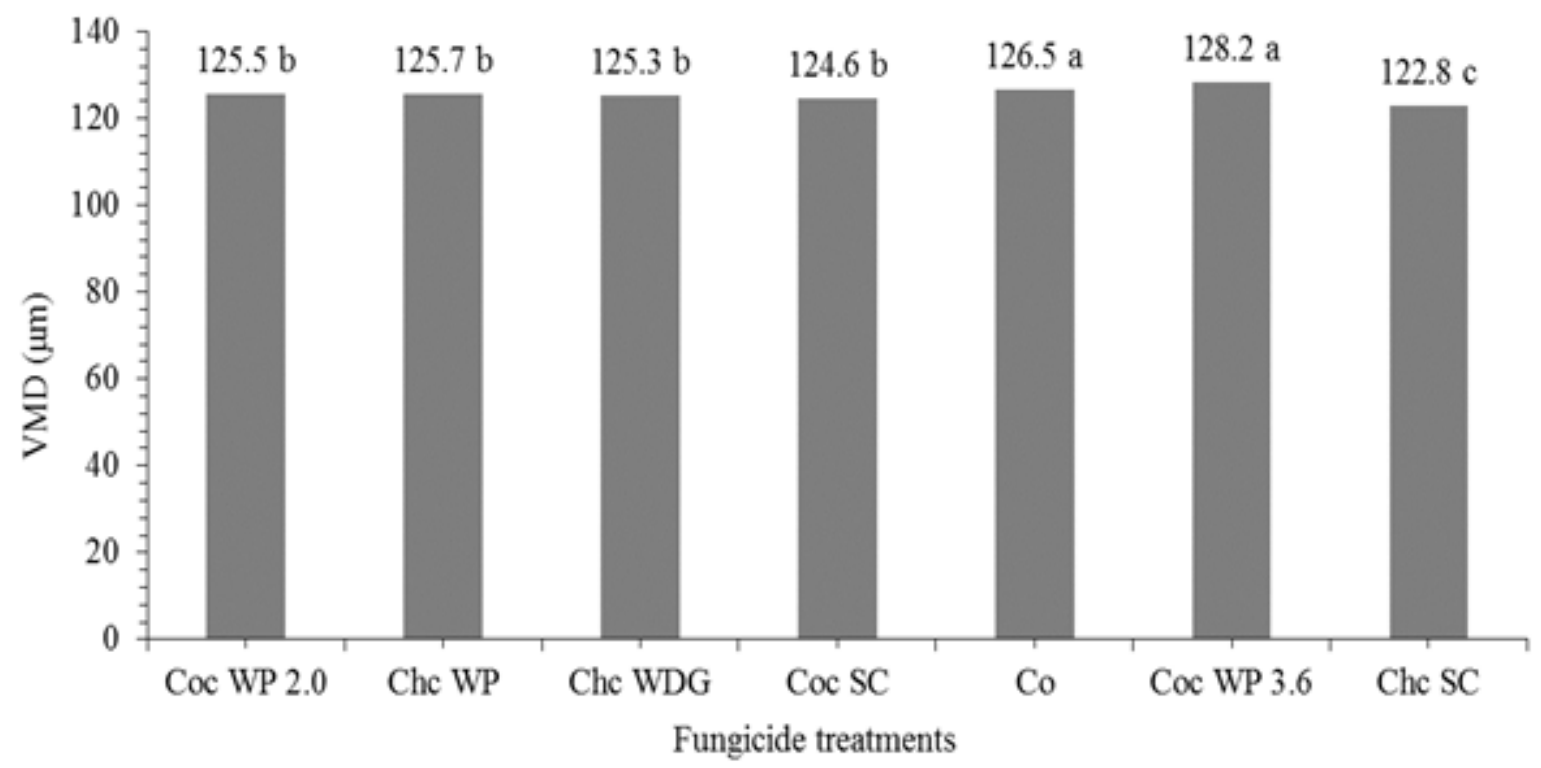

Figure 2. Volumetric median diameter $(\mathrm{VMD})$ of solutions with copper fungicides. $\mathrm{Coc}=$ Copper oxychloride; Cho $=$ Copper hydroxide; $\mathrm{Co}=$ Copper oxide; $\mathrm{SC}=$ suspension concentrate, $\mathrm{WP}=$ wettable powder, $\mathrm{WDG}=$ water dispersible granules.

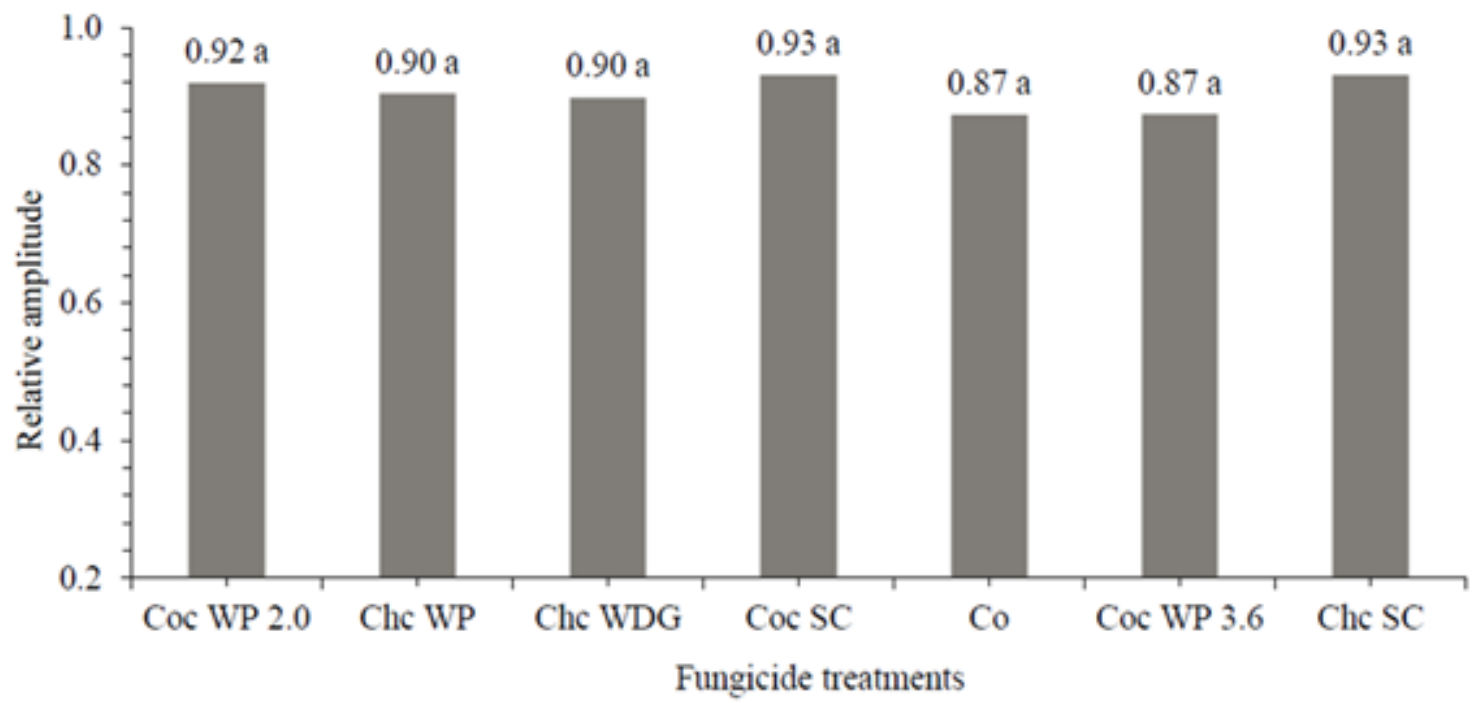

Figure 3. Relative amplitude of solutions with copper fungicides. $\mathrm{Coc}=$ Copper oxychloride; $\mathrm{Cho}=$ Copper hydroxide; Co $=$ Copper oxide $\mathrm{SC}=$ suspension concentrate, $\mathrm{WP}=$ wettable powder, $\mathrm{WDG}=$ water dispersible granules.

The mean values of percentage of drops $<100$ $\mu \mathrm{m}$ in the treatments (Figure 4,) ranged from 24 to $29 \%$. Treatments with copper oxychloride (WP; 3.6 $\mathrm{kg} / 2000 \mathrm{~L}$ ) and copper oxide differ from other treatments, with the lowest percentages (24.2 and $25.3 \%$, respectively). Copper hydroxide and copper oxychloride (SC) had percentages of 29.4 and $27.7 \%$, respectively. Copper oxychloride SC had $12 \%$ more drops $<100 \mu \mathrm{m}$ than the WP (3.6 $\mathrm{kg} / 2000 \mathrm{~L})$. This results can be explained by the fact that copper oxychloride SC present particle sizes close to $1 \mu \mathrm{m}$, while other copper oxide solutions 
had particle size between 3 and $6 \mu \mathrm{m}$, and by the product formulation (SC), which contains surfactants such as adhesives and hydro resistant agents.

SC have advantages over other formulations, reducing loss by drifting and surface tension (Table 3 ), improving the performance of drops and application, reducing evaporation and increasing the spray retention time on target. Cunha et al. (2010) reported that there is no default value indicative of drift risk or a secure application, however, Cunha et

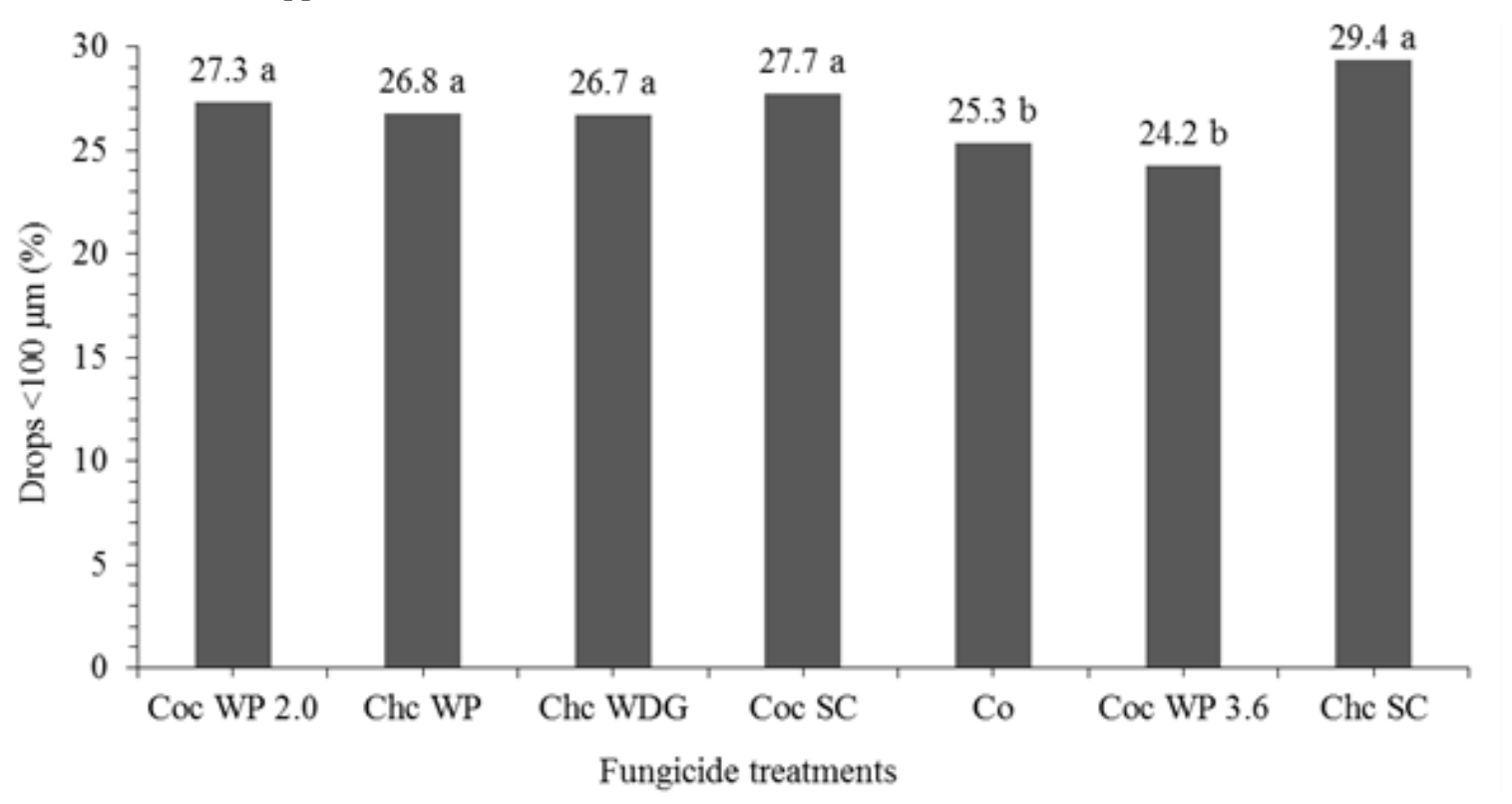

Figure 4. Percentage of drops with diameter smaller than $100 \mu \mathrm{m}(\%<100 \mu \mathrm{m})$ from solutions with copper fungicides. Coc $=$ Copper oxychloride; Cho = Copper hydroxide; $\mathrm{Co}=$ Copper oxide; $\mathrm{SC}=$ suspension concentrate, $\mathrm{WP}=$ wettable powder, $\mathrm{WDG}=$ water dispersible granules.

There was no statistical difference in percentage of drops $<150$ and $<200 \mathrm{uM}$ between the evaluated copper fungicides (Figure 5), which ranged from 96.0 to $96.9 \%(<200 \mu \mathrm{m})$ and from 64.2

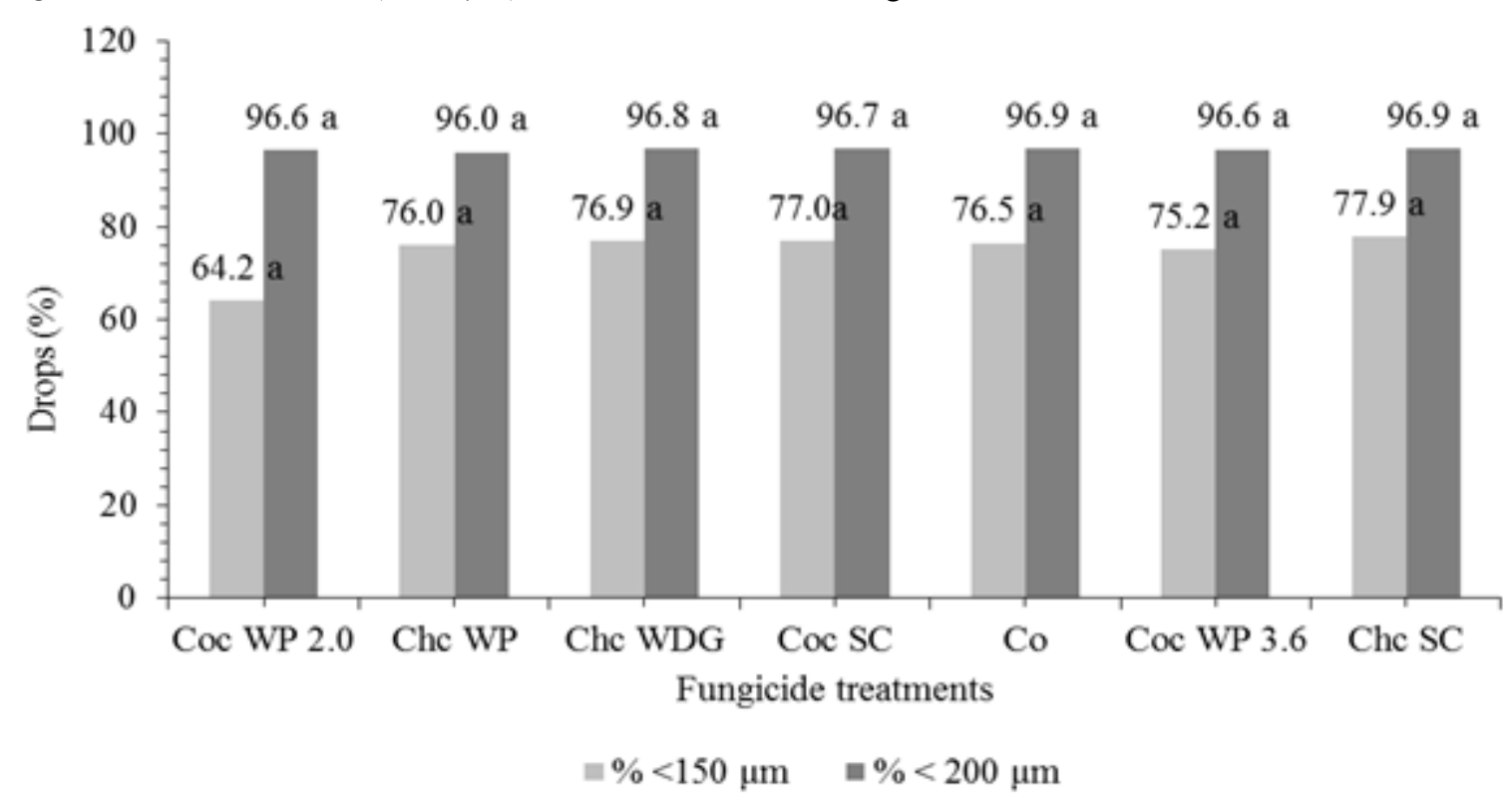

al. (2003) stated that, in general, values of drops with diameter $<100 \mu \mathrm{m}$ lower than $15 \%$ are most suitable for a safe application. Mathews (2000) stated that the appropriate drop size is essential for the deposition of the active ingredient on the correct target and that drops between 50 and $100 \mu \mathrm{m}$ (very fine drop) can be carried into the leaf mass by air turbulence and deposited on the leaves, but they can also evaporate before they reach the target. 
The drops of $<100 \mu \mathrm{m}(\%)$ presented an inversely and significantly linear relation to the
VMD, i.e., the increase in VMD decreased the percentage of drops $<100 \mu \mathrm{m}$ (Figure 6).

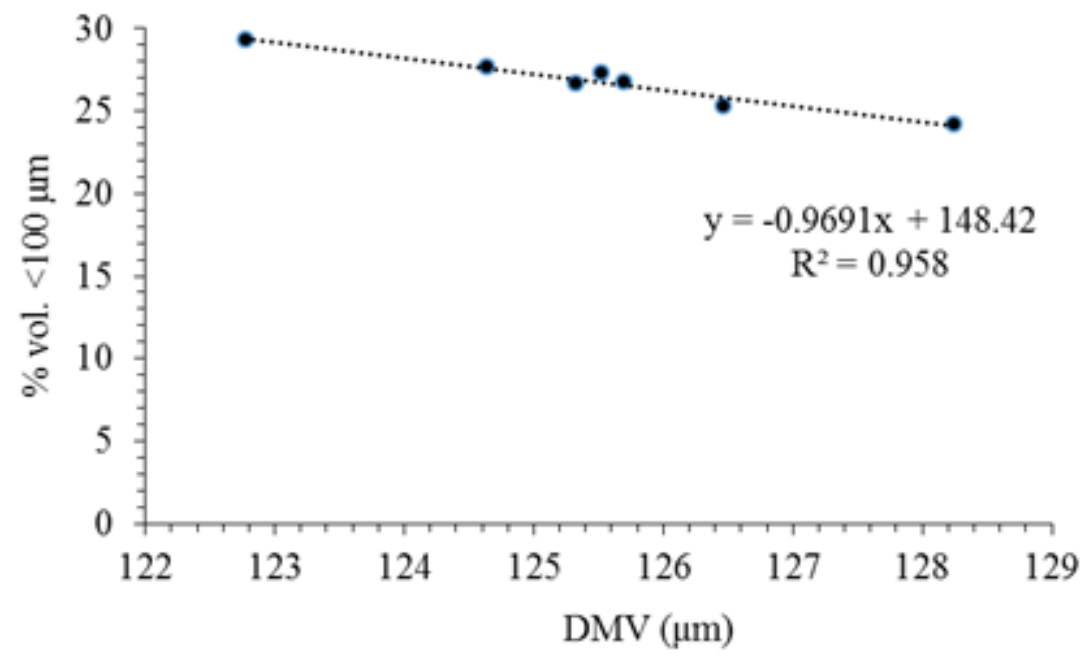

Figure 6. Percentage of drops $<100 \mu \mathrm{m}$ depending on the volumetric median diameter (VMD) from solutions with copper fungicides.

There was a correlation between the variables of spectrum of drops from the different solutions with copper fungicides (Table 2).

The copper content retained in the leaves of citrus seedlings after simulated rainfall of $20 \mathrm{~mm}$ (point of dripping) had average values from zero (processing in which the solution had no application copper fungicides) to $14.5 \mathrm{mg} \mathrm{L}^{-1}$, which was reached with copper oxychloride (SC), statistically differing from the control and other copper fungicides (Table 3).

The copper oxide fungicide presented the lowest copper content in the leaves $\left(3.3 \mathrm{mg} \mathrm{L}^{-1}\right)$ (Table 3), differing only from the control, however, $69.5 \%$ of the copper was retained on the leaves. Decaro Junior (2013) stated that consider the rainfall is essential in spraying in seedlings, since it can reduce the deposited solution content as early as the first precipitated millimeters.

The addition of surfactants in the solution such as silicone adhesive makes the active ingredient to adhered to the leaf surface. Hydro resistant agent is another surfactant used in the solution, forming a protective film against rainfall. The amount of surfactants in the fungicides of SC formulation (copper oxychloride and hydroxide) was considered suitable, reducing the drift potential and providing greater contact of the spray mixture with the plant surface. According to Hock (2004), when a surfactant is not appropriately used, the active ingredient efficiency of a pesticide can be reduced and the risk of toxicity to the treated plant increased.

Table 2. Correlation between the drops spectrum variables of fungicide solutions.

\begin{tabular}{cccc}
\hline & Standard Deviation & VMD & \% of drops $<100 \mu \mathrm{m}$ \\
\hline VMD & 1.67 & & \\
\% of drops $<100 \mu \mathrm{m}$ & 1.65 & -0.98 & 0.92 \\
Relative amplitude & 0.02 & -0.84 & \\
\hline
\end{tabular}

$\mathrm{VMD}=$ volumetric median diameter. 
Table 3. Fungicide copper contents, retention of copper and surface tension of citrus seedlings sprayed with copper fungicides of different formulations.

\begin{tabular}{|c|c|c|c|c|c|c|}
\hline Treatments & $\begin{array}{l}\text { Copper Content } \\
\qquad\left(\mathrm{mg} \mathrm{L}^{-1}\right)\end{array}$ & & $\begin{array}{l}\text { Copper retention } \\
\qquad\left(\mathrm{mg} \mathrm{cm}^{-2}\right)\end{array}$ & & $\begin{array}{l}\text { Surface tension } \\
\qquad\left(\mathrm{mN} \mathrm{m}^{-1}\right)\end{array}$ & \\
\hline Copper hydroxide WP & 4.8 & $\mathrm{~b}$ & 14.6 & $\mathrm{~b}$ & 57.8 & $\mathrm{~b}$ \\
\hline Copper hydroxide WDG & 5.4 & $\mathrm{~b}$ & 14.9 & $\mathrm{~b}$ & 57.6 & $\mathrm{~b}$ \\
\hline Copper oxychloride WP 2.0 & 4.9 & $\mathrm{~b}$ & 16.5 & $\mathrm{~b}$ & 53.8 & $\mathrm{c}$ \\
\hline Copper oxide & 3.3 & $\mathrm{~b}$ & 13.7 & $\mathrm{~b}$ & 51.2 & $\mathrm{~d}$ \\
\hline Copper oxychloride WP 3.6 & 5.2 & $\mathrm{~b}$ & 15.5 & $\mathrm{~b}$ & 43.1 & $\mathrm{e}$ \\
\hline Copper hydroxide SC & 7.3 & $\mathrm{~b}$ & 10.4 & a & 32.0 & $\mathrm{f}$ \\
\hline Copper oxychloride SC & 14.5 & $\mathrm{a}$ & 9.3 & $\mathrm{a}$ & 31.6 & $\mathrm{f}$ \\
\hline Control (Water) & 0.0 & $\mathrm{c}$ & 25.5 & $\mathrm{c}$ & 72.0 & $\mathrm{a}$ \\
\hline F Value & 33.646 & $* *$ & 4.652 & $* *$ & 1728.972 & $* *$ \\
\hline $\mathrm{CV}(\%)$ & 25.16 & & 18.98 & & 1.17 & \\
\hline
\end{tabular}

** Significant at $1 \%$ probability. Means followed by the same letter do not differ.

The retention of copper in leaves that received application of copper oxychloride (SC) $(9.3$ $\mathrm{mg} \mathrm{cm}{ }^{-2}$ ) and copper hydroxide (SC) $\left(10.4 \mathrm{mg} \mathrm{cm}^{-2}\right)$ was the lowest compared to other fungicides and formulations (Table 3), thus confirming that the SC formulations result in less solution retained per $\mathrm{cm}^{2}$ of leaf area and hence the spray input in citrus leaves.

The surface tension of water is $72 \mathrm{mN} \mathrm{m}^{-1}$, the highest among the treatments. The fungicide copper oxychloride (WP; $2.0 \mathrm{~L} / 2000 \mathrm{~L}$ ) and copper hydroxide (WDG) had surface tension between 53 and $57 \mathrm{mN} \mathrm{m}^{-1}$. On the other hand, the fungicides copper hydroxide $\left(32.0 \mathrm{mN} \mathrm{m}^{-1}\right)$ and oxychloride (SC) $\left(31.6 \mathrm{mN} \mathrm{m}^{-1}\right)$ had the lowest surface tensions (Table 3).

Copper fungicides of SC formulation contain surfactants such as silicone adhesives and hydro resistant agent that allow a better spreading and contact between the drops and the plant surface. Tu and Randall (2003) stated that the surfactants are widely used for a better contact between the drops and the surface, increasing the plant absorption rate, providing a more uniform spread, reducing evaporation and increasing the solution retention in the plant. The drops sprayed on the leaves can fragment into smaller drops depending on their size, speed, physicochemical properties of the solution and leaf surface characteristics, and grant desirable characteristics to spray solution, allowing greater contact with the plant surface or reducing the drift potential during spraying.

\section{CONCLUSIONS}

Copper fungicides of SC formulations have the lowest surface tension, granting a greater tenacity and persistence of copper on the leaves of citrus seedlings after simulated rainfall, increasing the contact between the drop and leaf surface and the protection time in citrus seedlings.

\section{REFERENCES}

ANTUNIASSI, U. R.; BAIO, F. H. R. Tecnologia de aplicação de defensivos. In: VARGAS, L.; ROMAN, E. S. Manual de manejo e controle de plantas daninhas. Passo Fundo: Embrapa Trigo, 2008. p. 174-175.

ASAE - AMERICAN SOCIETY OF AGRICULTURAL ENGINEERING. Spray nozzle classification by droplet spectra. St. Joseph: 2000. p. 389-391.

CABRAS, P. et al. The effect of simulated rain on folpet and mancozeb residues on grapes and on vine leaves. Journal of environmental Science and Health, New York, v. 36, n. 5, p. 609-618, 2001.

CAMARA, F. T. et al. Distribuição volumétrica e espectro de gotas de bicos hidráulicos de jato plano de faixa expandida XR11003. Engenharia Agrícola, Jaboticabal, v. 28, n. 4, p. 740-749, 2008.

CANTERI, M. G. et al. SASM-AGRI - Sistema para 
análise e separação de médias em experimentos agrícolas pelos métodos Scott- Knott, Tukey e Duncan. Revista Brasileira de Agrocomputação, Ponta Grossa, v. 1, n. 2, p. 18-24, 2001.

CUNHA, J. P. A. R. et al. Avaliação de estratégias para redução da deriva de agrotóxicos em pulverizações hidráulicas. Planta Daninha, Viçosa, v. 21, n. 2, p. 325-332, 2003.

CUNHA, J. P. A. R.; BUENO, M. R.; FERREIRA, M. C. Diâmetro de gotas de pontas de pulverização com adjuvantes de uso agrícola. Planta Daninha, Viçosa, v. 28, Sup., p. 1153-1158, 2010.

DECARO JUNIOR, S. T. Avaliação de um pulverizador de volume ultra baixo na cultura do café para o controle de Leucoptera coffeella (lepidoptera: lyonetiidae). 2013. 102 f. Dissertação (Mestrado em Produção Vegetal) - Departamento de fitossanidade, Universidade Estadual Paulista, Jaboticabal, 2013.

ETHERIDGE, R. E.; WOMAC, A. R.; MUELLER, T. C. Characterization of the spray droplet spectra and patterns of fourventuri-type drift reduction nozzles. Weed Technology, Lawrence, v. 13, n. 4, p. 765-70, 1999.

FERREIRA, M. C. et al. Fatores qualitativos para a ponta hidráulica de jato plano ADGA 110015 na pulverização agrícola. Engenharia Agrícola, Jaboticabal, v. 27, n. 2, p.115-120, 2007.

HARDY, S.; FALLOW, K.; BARKLEY, P. Using Cooper sprays to control diseases in citrus. Sidney, NSW: PRIMEFACTS, 2007. 5 p.

HOCK, W. K. Horticultural spray adjuvants. Harrisburg, PA: UPENN, 2004. 4 p. (Agrichemical fact Sheet, 11).

HUNSCHE, M. et al. Mancozeb wash-off from apple seedlings by simulated rainfall as affected by drying time of fungicide deposit and rain characteristics. Crop Protection, Bonn, v. 26, n. 5, p. 768-774, 2007.

MATTHEWS, G. A. Pesticide application methods. 3. Ed. Oxford: Blackwell Science, 2000. $432 \mathrm{p}$.

MOTA, A. A. B. Quantificação do ar incluído e espectro de gotas de pontas de pulverização em aplicações com adjuvantes. 2011. 74 f. Dissertação (Mestrado em Agronomia/Energia na Agricultura) Faculdade de Ciências Agronômicas, Universidade Estadual Paulista, Botucatu, 2011.

RICH, S. Dynamics of deposition and tenacity of fungicides. Phytopathology, Saint Paul, v. 44, n. 1, p. 203-213. 1954.

SUHERI, L.; LATIN, C. Retention of fungicides for control of Alter aria leaf blight of muskmelon under greenhouse conditions. Plant Disease, West Lafayette, v. 75, p. 1013-1015, 1991.

TU, M.; RANDALL, J. M. Adjuvants. In: TU, M. et al. Weed control methods handbook the nature conservancy. Davis: TNC, 2003. p. 1-24.

WEBER, A. L. et al. Influence of different materials on coverage and adhesiveness of sprays and their effect on residue removal from apples. New Jersey Agricultural Experimental Station Bulletin, New Jersey, v. 2, n. 1, p. 1-16. 1937. 